\title{
ROAD ASSET CLASSIFICATION SYSTEM
}

\author{
M. Gkovedarou, I. Brilakis \\ Department of Engineering, University of Cambridge, Cambridge, United Kingdom
}

\begin{abstract}
Visual inspection is the most commonly employed way of condition inspection for road networks. The process is quite labor intensive, leading to a substantive cost of inspection per lane mile and causing long inspection cycles and substantive inspection outcomes variability. Automating the process can tackle these issues. The first step to achieve automation is to understand what the assets are, what their visible condition symptoms are, what they cause and what causes them, and how to fix both their outcomes and their causes. This is the objective of this paper. Inspired by the symptoms tracker of WebMD, we conducted exploratory research that combined several guidelines into a comprehensive definition of road assets, their defects and possible maintenance techniques from the road inspector's point of view. We propose a different classification system of the road assets according to their defects and maintenance techniques driven by the computer visual monitoring approach. The result is a large map containing all the aforementioned elements.
\end{abstract}

\section{Introduction}

Highway Operational Standards 2018-2028 refer to the importance of healthy highway infrastructure as the key for a robust economy stating the need to use all the available resources (Highway Operational Standards, 2018). A publication by the United Kingdom Royal Society for the Prevention of Accidents states the importance of healthy road assets (pavement, signs, markings etc.) as they constitute a huge factor for the safety of road users (International Road Federation, 2006). Their maintenance is essential (Levik, 2001) and cost effective compared to complete road reconstruction (Medd, 2009). As a result, the identification and the measurement of the road defects (as part of maintenance policy) is quite challenging, rendering the use of suitable advanced technologies essential. There are three maintenance categories (Burningham and Stankevich, 2005):

- Routine Maintenance, which is conducted on a regular basis and entails debris removal, minor repairs etc.

- Periodic Maintenance, which is also conducted on a regular basis but is more costly than the routine maintenance, as it includes pavement reconstruction, Planning and Strategy

- Urgent Maintenance, which includes repairs that could not have been foreseen
The United Kingdom (UK) road expenditures for the year 2015-2016 were $£ 9$ bn. and $40 \%$ of them were allocated for the maintenance ( $£ 3.6$ bn.). From this amount, 20\% (£0.72 bn.) constituted the routine maintenance and the planning and strategy of the maintenance policy, which also represents the area of interest of this paper (Figure 1) (George and Kershaw, 2016).

The maintenance policy of the authorities in the UK is both expensive (Figure 1) and time consuming (Table 1).

Road Expenditures for $\left({ }^{‘} 15-{ }^{‘} 16\right)=£ 9 \mathrm{bn}$.

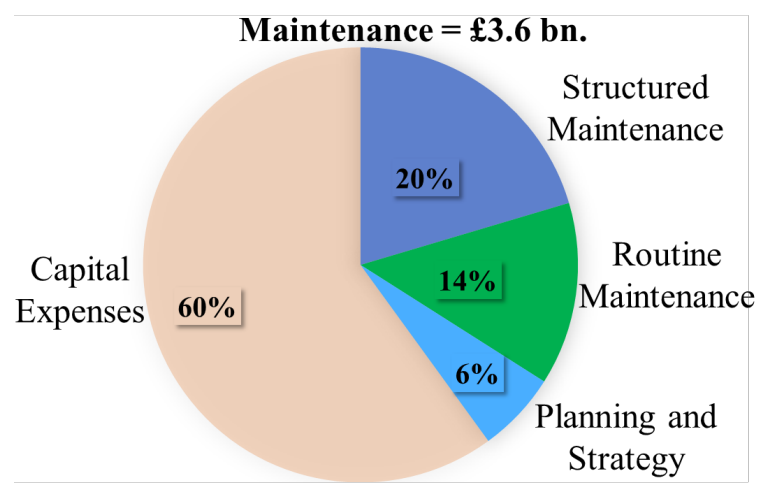

Figure 1: Allocation of road expenditures for the UK (2015-2016) (George and Kershaw, 2016).

Road maintenance monitoring occurs once or twice per year for the motorways and once per two years for the minor roads (Highway Operational Standards, 2018). This inspection is mainly visual for road assets like lights, barriers and the drainage system (Royal Borough of Windsor and Maidenhead, 2017).

Currently, Fugro (Roadware, 2010) has released a dedicated vehicle: the Automatic Road Analyzer 9000 (ARAN) which is equipped with video cameras or optical sensors, lasers, ultrasonic sensors, accelerometers and automatically detects defects like longitudinal cracks, transverse cracks, potholes and rutting (Department for Transport, 2017). In the United Kingdom, Highways England and the Local Authorities (responsible for the road maintenance) use TRACS (TRAffic - speed Condition Surveys) survey vehicles and SCANNNER (Surface Condition Assessment for the National Network of Roads) survey vehicles respectively, to collect data of pavement. They automatically collect geometry and condition data that can be used to manually 
detect/model cracks (through image processing), bumps, potholes, gradient, crossfall, radius and curvature of road and the retro-reflectivity of road demarcation.

Table 1: Type and Inspection Frequency on the UK roads (Highway Operational Standards, 2018).

\begin{tabular}{|c|c|}
\hline $\begin{array}{l}\text { Hierarchy } \\
\text { Description }\end{array}$ & $\begin{array}{l}\text { Inspection frequency and type } \\
\text { from City Councils }\end{array}$ \\
\hline Motorway & $\begin{array}{l}\text { 1-2 per year (from Highways } \\
\text { England) }\end{array}$ \\
\hline $\begin{array}{l}\text { Strategic } \\
\text { Route }\end{array}$ & 12 times per year (monthly) \\
\hline $\begin{array}{l}\text { Main } \\
\text { Distributor }\end{array}$ & 12 times per year (monthly) \\
\hline $\begin{array}{l}\text { Secondary } \\
\text { Distributor }\end{array}$ & 12 times per year (monthly) \\
\hline Link Road & 4 times a year ( 3 monthly) \\
\hline $\begin{array}{l}\text { Local Access } \\
\text { Road }\end{array}$ & Annually (once per year) \\
\hline Minor Roads & $\begin{array}{l}1 \text { per two years ( } 24 \text { monthly) } \\
\text { (standard is that they are } \\
\text { passable with care) }\end{array}$ \\
\hline $\begin{array}{l}\text { Soft Roads } \\
\text { (Green Lanes) }\end{array}$ & $\begin{array}{l}\text { No formal inspection regime. } \\
\text { Inspected on a reactive basis } \\
\text { (standard is that they are } \\
\text { passable in a } 4 \text { wheel drive } \\
\text { vehicle) }\end{array}$ \\
\hline
\end{tabular}

\section{Discussion and Analysis}

The aim of this paper is to introduce a classification system of the road assets that is based on these computer vision inspection methods. For the scope of this paper road manuals from four parts of the world were used: United Kingdom, Hong Kong (Special Administrative Region of the People's Republic of China), California (United States of America) and Queensland (Commonwealth of Australia) to define the asset types. Next, the grouping of these types follows according to a) possible common defects that they might have and b) their geometrical structure and visual differences, as these characteristics affect the automated detection of these assets.

Most of the manuals specify in a first level the general road asset type and then in a second level the road furniture (asset group) that level one entails. The UK (Roads Liaison Group, 2010) follows this pattern for levels one, two and three (Table 2). The table illustrates a sample of the road manuals and the rest are part of the Appendices. The Hong Kong manual [13] is not as elaborative as the UK one and the asset types are slightly different (Table A.1). "Street lighting", "Slopes" and "Landscape Enhancement and
Vegetation" asset groups here are considered as main standalone asset types (Level 1) whereas in the UK manual they are in Level 2. The Queensland manual introduces a new category of road assets; the Intelligent Transportation System (ITS) Elements (Table A.2). ITS are deemed as advanced information and technological systems, which are

placed on the road infrastructure system [14]. The "Roads" and "Structures" types remain as main categories similar to the UK and Hong Kong manuals (Table A.3). The rest of the asset types are not extensively described. The "Intelligent Transportation System (ITS) Elements" category makes up a main asset type in the California manual as well (Table A.3) (Indicators, 2016).

The asset types defined in the manuals were classified into categories for construction and maintenance purposes. These categories are used to redefine these raw asset types in a different way aiming to introduce new asset types and asset groups that will facilitate road assets monitoring. Firstly, the asset types and groups, described in the above manuals, are gathered to gain a clear view of the number, type and groups of the road assets that are (Figure 3). The next step is to create different asset categories based on:

1) their possible defects

2) their geometrical characteristics.

In the following section, the road asset types and groups are analysed and redefined using the above criteria.

\section{a) "Pavement" Asset Type}

There are four different pavement groups: the "rigid", "rigid composite", "flexible" and "flexible composite" pavement (Roads Liaison Group, 2010) (Figure 1.2). The difference between "rigid" and "flexible" is that the road base of the first is cement whereas for the second, the road base is bitumen. Composite pavement is a pavement structure, which has flexible and rigid layers. These pavements usually have one or more asphalt concrete layer on top of a Portland cement concrete slab ("flexible composite"), although some have a typical composite structure is with the Portland cement concrete slab on top of asphalt concrete ("rigid composite") (Figure 1.2) (Highways Agency, 2006). The author suggests the merge of the four categories of these road asset groups into two: "Concrete Pavement" and "Asphalt Pavement" as the visual characteristics and defect approximation is based on the material of the pavement. The asphalt pavement is analyzed by Hadjidemetriou G.M., Masino J., Christodoulou S.E., Gauterin F, and Brilakis I. in a paper reviewed (2018) for publication by ASCE The reason of this combination is that:

1) The material of the pavement (asphalt or concrete) is the main factor of the pavement defects, as it is 
described in the following section (defect criterion).

2) The surface of the flexible pavement and the flexible composite is usually black due to the asphalt material, whereas, the rigid pavement and the rigid composite is light grey (visual characteristics).

b) "Road Furniture" Asset Type

Concerning the "road furniture" asset type, the "vegetation" asset group has the same characteristics with the "hedges" as both of them are related to planting and their only defect will be the overgrowth process. This overgrowth, for example, might lead to hidden traffic signs, which constitutes a defect of the "signs" group. For this reason, "vegetation" and "hedges" will not be included in the road assets groups, for the purposes of this paper, as the only problem they might create is overgrowth and this can be included in the "Signs" defects. The "fences" category is closer to the "Barriers" and "guardrails" groups as these have similar geometrical characteristics and also similar defects (The Government of the Hong Kong Special Administrative Region, 2018). Thus, a new group named as "Barriers" is defined that includes the aforementioned road groups. The road "Markings" group includes both mechanical markings (raised pavement markings) like cat's eyes, botts' dots etc. and the road surface markings (Highways, 2015). The "Demarcation" category as a new category that will include raised pavement markings. The road surface (coloured surface) marking should be a different asset category as they have different defect types and different visual and geometrical characteristics from the raised pavement markings.

"Shoulder / hard strip" is, in practice, an emergency lane (pavement) distinguished by either "road markings" or other "demarcation" asset groups. It has the same visual / geometrical characteristics and similar expected defects to the "Pavement" asset type, thus, it will be part of the "Pavement" asset type. The "verge" asset group usually consists of soil or grass, is placed at the edge of the road and may have the same defects as the "vegetation" group and could be included in the "vegetation" category as defined above (Heath, 1999). In this research, "earthworks" will not be considered as a road asset group since the result of earthwork distress (like landslide for example) is a visible deterioration of the road pavement (detectable stones, soils on the pavement etc.)

Typical Composite Pavement

Typical Asphalt Pavement

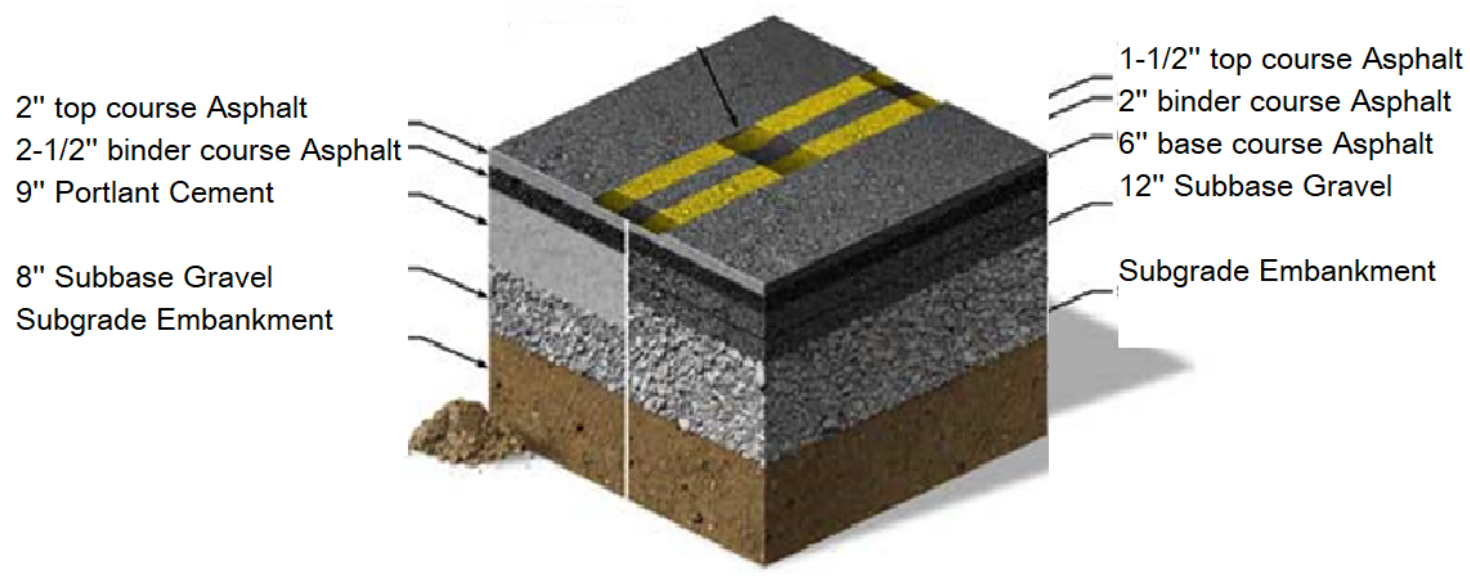

\section{Types of road construction}

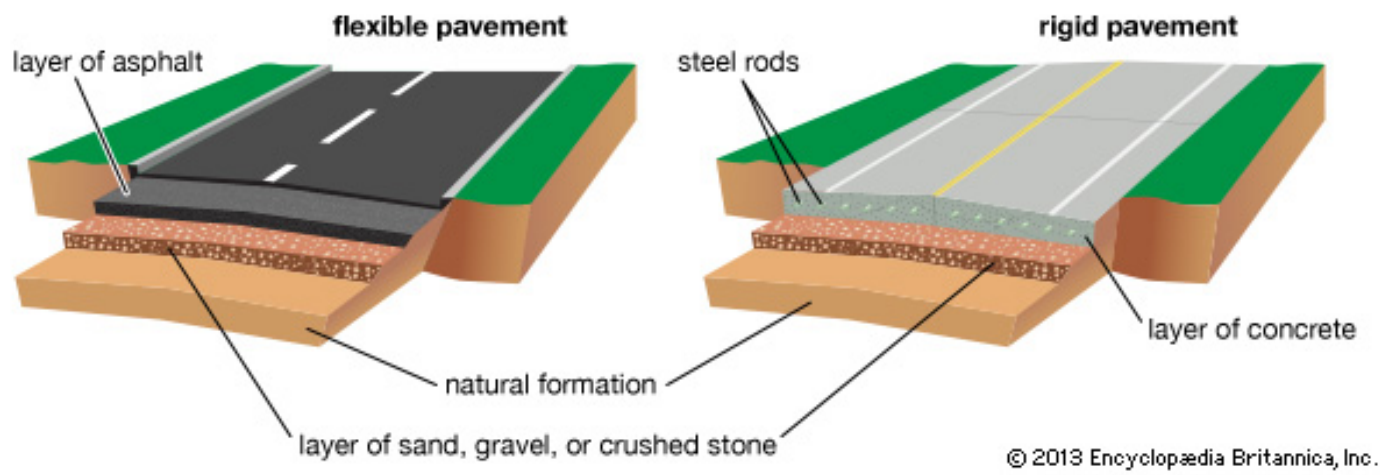

Figure 2: Layers of (left) flexible pavement, (right) rigid pavement and asphalt composite pavement in comparison to asphalt pavement (down) [16] 
Table 2: Road assets and sub categories (UK Manual) (Roads Liaison Group, 2010)

\begin{tabular}{|c|c|c|}
\hline $\begin{array}{c}\text { Level } 1 \\
\text { Asset Type }\end{array}$ & $\begin{array}{c}\text { Level } 2 \\
\text { Asset Group }\end{array}$ & Level 3: Components \\
\hline Road & $\begin{array}{l}\text { - Flexible pavements } \\
\text { - Flexible composite pavements } \\
\text { - Rigid concrete pavements } \\
\text { - Rigid composite pavements }\end{array}$ & $\begin{array}{l}\text { - Pavement layers (formation, road base, } \\
\text { binder course, surface course) } \\
\text { - Other surface types e.g. paved } \\
\text { - Hard strip/shoulder } \\
\text { - Footway/ cycleway attached to road } \\
\text { - Central reservation, roundabout, lay-by } \\
\text { etc. } \\
\text { - Markings } \\
\text { - Kerbs } \\
\text { - Earthworks (embankments \& cuttings) } \\
\text { - Vegetation } \\
\text { - Drainage } \\
\text { - Safety fences } \\
\text { - Boundary fences and hedges } \\
\text { - Verges }\end{array}$ \\
\hline $\begin{array}{l}\text { Segregated } \\
\text { footpaths } \\
\text { and cycle } \\
\text { routes* }\end{array}$ & $\begin{array}{l}\cdot \text { - Footpath (including PROW) } \\
\text { - Bridleways (including PROW) } \\
\text { - Off road cycle routes } \\
\text { - Pedestrian areas }\end{array}$ & $\begin{array}{l}\text { - Binder course and surface course } \\
\text { - Formation }\end{array}$ \\
\hline Structures & $\begin{array}{l}\cdot \text { - Bridges (includes subways) } \\
\cdot \text { Culverts (span }<1.5 \mathrm{~m} \text { ) } \\
\text { - Retaining walls } \\
\text { - Sign/signal gantries and } \\
\text { cantilever road signs } \\
\text { Other assets included in this group: } \\
\text { - Tunnels } \\
\text { - Structural earthworks, e.g. } \\
\text { strengthened/reinforced soils } \\
\text { - Fords and causeways } \\
\text { - Cattle grids }\end{array}$ & $\begin{array}{l}\text { Should include all components considered } \\
\text { in the maintenance and management of } \\
\text { these assets. } \\
\text { Smaller water carrying structures are } \\
\text { considered as road drainage. }\end{array}$ \\
\hline $\begin{array}{l}\text { Highway } \\
\text { lighting and } \\
\text { high mast lighting }\end{array}$ & $\begin{array}{l}\cdot \text { - Lighting columns } \\
\text { - Lighting unit attached to wall } \\
\text { - High mast lighting }\end{array}$ & $\begin{array}{l}\text { - Column and foundations } \\
\text { - Bracket } \\
\text { - Luminaire (or other fixtures, e.g. CCTV) } \\
\text { - Control gear, switching and internal } \\
\text { wiring cabling }\end{array}$ \\
\hline
\end{tabular}


(The Local Government \&Municipal Knowledge Base, no date). The "Drainage" asset group used in urban roads are: kerbs \& gullies, combined kerb \& drainage blocks, linear drainage channels and combined surface and ground water filter drains (Department of the Environment Heritage and Local Government, 2004). There is no reason to remove this asset group so it stays as it is.

\section{c) "Electronic Furniture" Asset Type}

The "Electronic Furniture" category includes the "Changeable Electronic Message". Since this category is limited to this specific asset group, a new category is defined instead the general category "Electronic Signs". This category includes LED (light - emitting diode) signs, the "changeable message signs", and any other type of electronic sign. "Lights" (included in this asset category) are usually in the traffic signs or in the top of the poles and are used to facilitate the road users' vision (Transport Infrastructure Ireland, 2017). The light poles are part of both of the lights and the lamps and they are considered as structures with similar defects as the ones of signs. In this case, only the lamp of the "light" or the "traffic sign" are considered as part of this group and not the support. The support (pole) could be part of the road furniture ("signs"). The "loop detector" comprises from a detector (usually a traffic signal) which is visible from the road user and a non-visible device buried under the earth. Once a vehicle passes over the loop, a magnetic field is created and the loop warns the vehicle detector, which in turn informs the light detector through the cable, and thus regulates traffic accordingly (Marszalek, Sroka and Zeglen, 2015). In a similar context, "ramp meters" also regulate traffic congestion by using a traffic light and a detector (loop buried in the road lane) that warns the traffic light if the vehicles can leave the ramp. A road inspector can understand from the traffic light if there is any defect in these two asset groups. It comprises of a support (pole) and an electronic device. Hence, the support could be part of the traffic signs since they have similar structure and defects and the device to be a separate part of the "Electronic Furniture" asset type.

"Structures" Asset Type

The structure asset category is out of the research scope of this research as there are different types of defects that are related to structural engineering and this category demands a different type of monitoring.

The new asset types, groups and the components that they might include, from the scope of the road inspector, are summarised in and shown in Figure 1.3

\section{"Concrete Pavement" Asset Type}

The defects of the second asset type, "Concrete Pavement", are: cracking (block, corner, diagonal, longitudinal, shrinkage and transverse cracking), deformation (joint stepping-faulting, rockingpumping), joint sealant defects, spalling (box out spalling) and surface texture defects (ravelling, loss of surface texture-slippery surface) (Research \& Development division of the Highway Department, 2013).

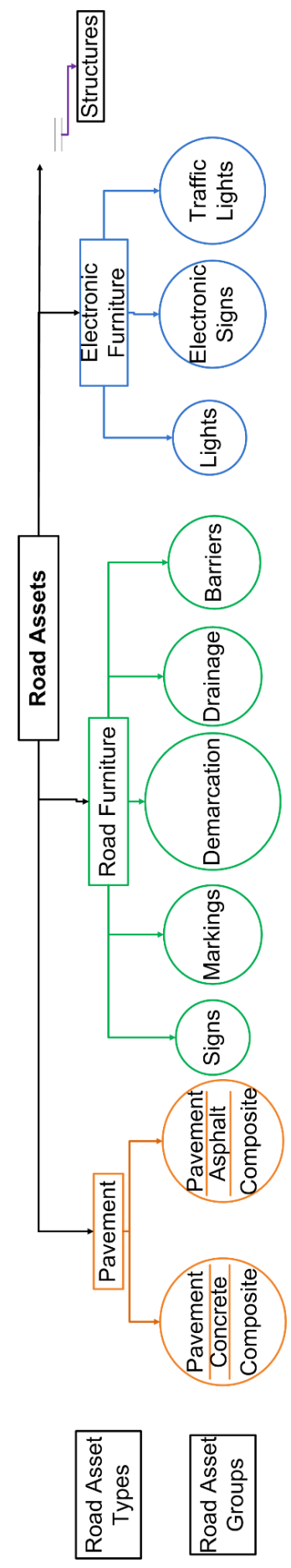

Figure 3: Road Assets final

The repair methods that correspond to each defect will follow. 
Table A.4 in the Appendix describes the maintenance techniques for the concrete pavements defects as found in the research. Table 3 indicates the corresponding defects that these techniques cure. The defects and the cures of the "Concrete Pavement" asset group will follow as it was analysed above (Figure 4). In Figure 1.4 , each color corresponds to the defect and is linked to the corresponding maintenance technique. The defects and the cures of the "Concrete Pavement" asset group will follow as analysed (Figure 4).

Table 3: Maintenance Techniques of "Concrete" Pavement type and Defects they cure

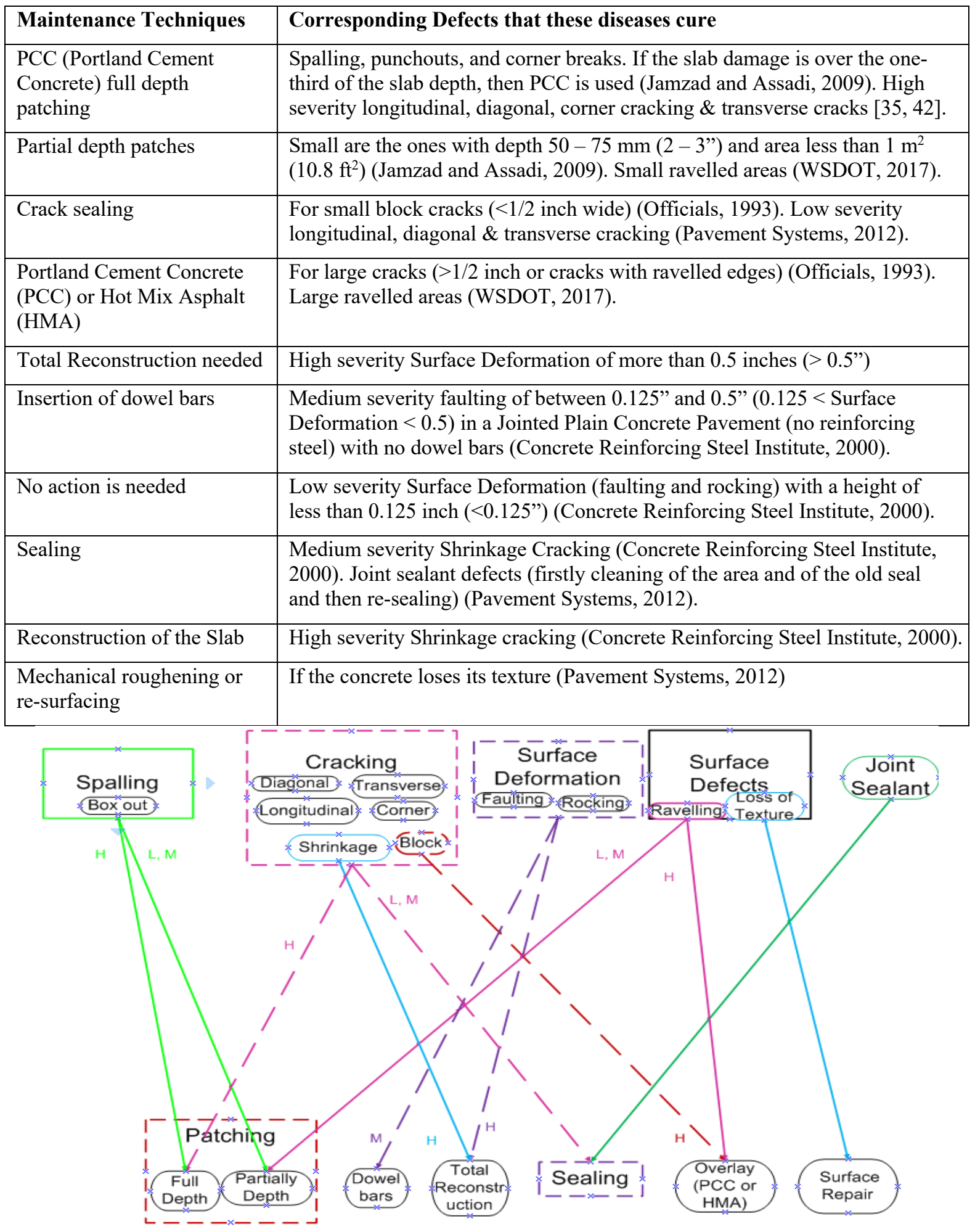

Figure 4: Defects (top) of the "Concrete Pavement" asset group and cures (bottom) according to the intensity of the defect: low $(L)$, medium $(M)$, high $(H)$ 


\section{"Road Furniture" Asset Type}

The second asset type is the road furniture comprising of "Signs", "Markings", "Demarcation", "Drainage" and "Barriers" asset group. For these groups, the possible defect categories are identified which affect the assets and their repair strategy. The majority of the road manuals describe extensively the first asset type ("Pavement") and its possible defects and repair techniques; they do not refer extensively to the road furniture though. Thus, for the research on the road furniture the UK city council websites were examined as they provide an online service where the citizens can report an issue on the road. Such councils are the Essex Country Council and the Norfolk Council. There are four categories of "Sign" defects: damaged, missing, dirty and faded (Essex Country Council, 2018). For the purposes of this research, all these defects (damaged, missing, dirty, faded) have been merged into one category since they require the same cure technique. The only defect that the road
"Markings" may face is fading. If over thirty per cent of their area is faded then they should be recovered. The "Demarcation" markings need replacement if they are either missing, damaged or not over $90 \%$ reflective, (Maintenance and Programme, no date). Soil, tree material or other vegetation material usually block or flood the drainage system, so the suggested maintenance technique is to be cleaned straightaway. In case the drainage system is near a slope, then it is suggested to apply a coarse material on the entire slope or to the bottom of the slope, (Holladay, 2014). The "Barriers" asset type entails the road "barriers", the "fences" and the "guardrails". The main defects of this category is to be either missing or destroyed. The maintenance techniques that are used are: replacement or renewal by repainting and cleaning, (UK Highways Agency, 2006). The defects and the cures of the "Road Furniture" asset type will follow as it was analysed above. The above analysis of the "Road Furniture" asset type defects is better represented in the Figure 5.

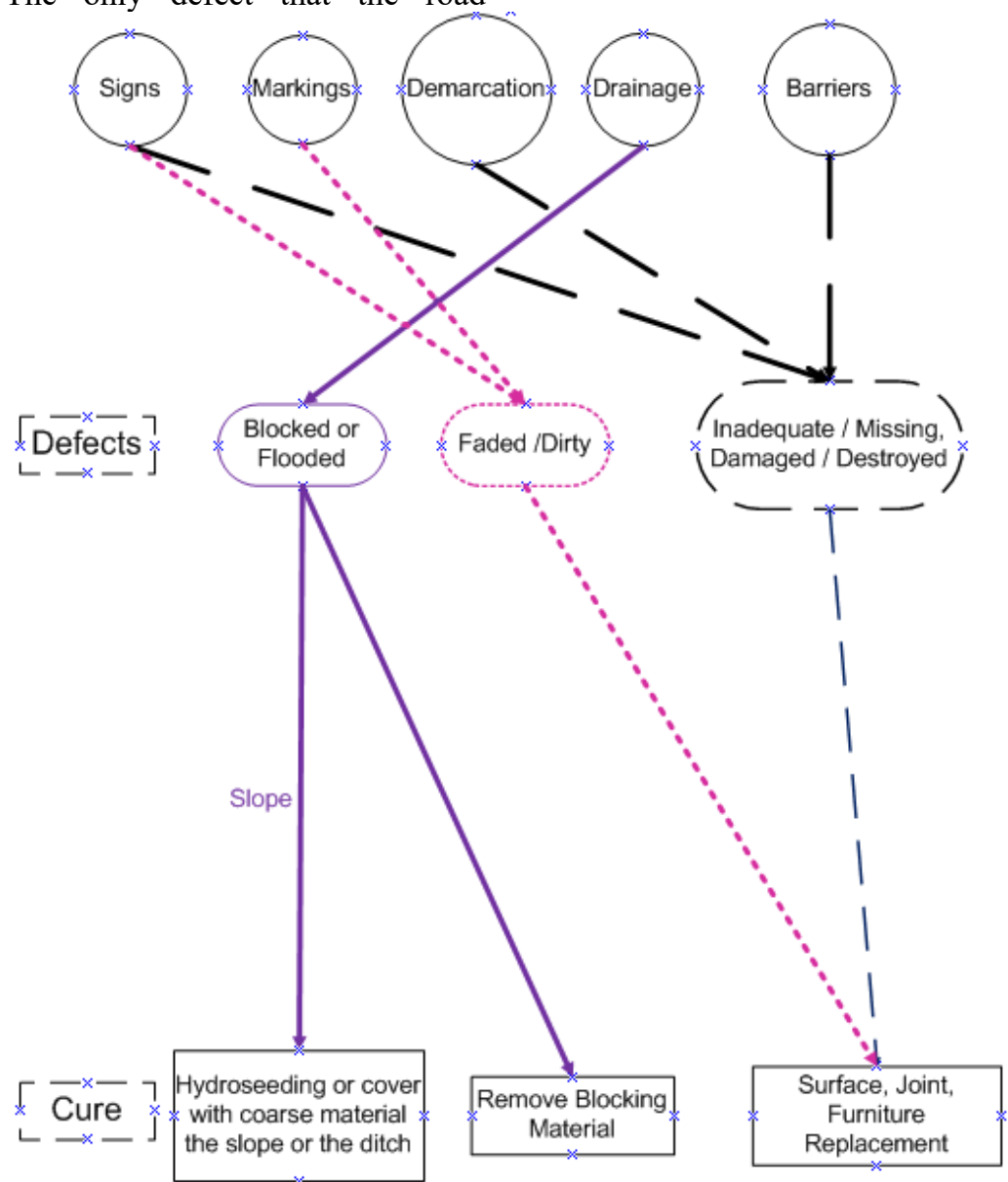

Figure 5: Defects (top) of the "Road Furniture" asset type and cures (bottom) 


\section{"Electronic Furniture" Asset Type}

The "Electronic Furniture" asset type comprises of the "Light", "Electronic Signs", and "Traffic Signs" asset groups. For each of these groups their plausible defects and corresponding maintenance techniques are analysed and then these defects and repair techniques are grouped. Light inspection entails electrical inspection (lightbulb) and structural inspection (pole of the light) ('STREET LIGHTING MAINTENANCE , MANAGEMENT PLAN ( Including Telematics )', 2015). The light pole might undergo the same defects as road signs (i.e., damaged, destroyed), hence, this part of the "Light" group will form part of the "Sign" asset group. Many city councils in the UK give road users the chance to report any type of lighting problem (Workingham, 2018). One of the options given is to report either a broken lamp or a lamp that works during the day as well. As soon as the authorities receive the report, they call a technician to repair the lamp. These plausible defects are merged into one category: "Not working properly". The "Electronic Signs" also face the same issues as they consist of an electronic sign and the structure that supports it. Following the same thought process, The structure is included in the "Sign" group category and the "Sign" in the "Light" category as they may face the same plausible defects. The inspection for the traffic lights is visual: either it is broken or does not work properly (switches on and off in a non-logical way). The maintenance techniques that are usually used are the rearrangement of loops, visual inspection every six months, replacement of the electronic units and electrical testing of the system (Adminmistartion, 2006). Figure 6 shows the previous analysis on the defects and the cures of the "Electronic Furniture" asset type.

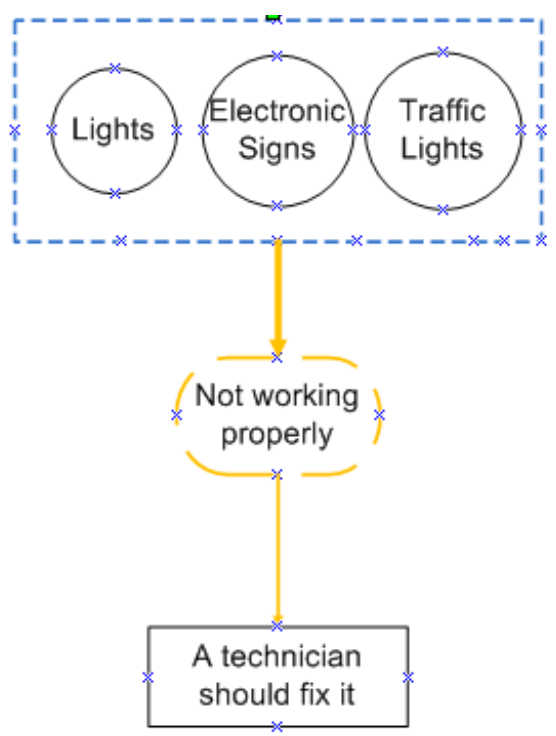

Figure 6: Defects (top) of the "Electronic Furniture" asset type and cures (bottom)

\section{Conclusions}

The sum-up of this analysis leaded to the definition of the road assets from the scope of the road inspector, which is analysed in the following figures (Figures 2-6). Through this classification, the inspector who uses computer vision techniques, could potentially reduce the time that spends on the road visual inspection.

\section{References}

Adminmistartion, F. H. (2006) Traffic Detector Handbook. Third. doi: FHWA-HRT-06-139.

Anon. (2010) 'DIRECTIVE 2010/40/EU OF THE EUROPEAN PARLIAMENT AND OF THE COUNCIL of 7 July 2010', Official Journal of the European Union, pp. 1-13. doi: COM(2010) 389 final.

Burningham, S. and Stankevich, N. (2005) 'Why road maintenance is important and how to get it done', Transport, (June), pp. 1-10. Available at: http://siteresources.worldbank.org/INTTRANSPORT/R esources/336291-1227561426235/5611053-

1231943010251/TRN4_Road_Maintenance.pdf.

Concrete Reinforcing Steel Institute (2000) 'Continuously Reinforced Concrete'.

Department for Transport (2017) 'Road Lengths in Great Britain: 2016', Statistical Release, 1(April). Available at: https:/www.gov.uk/government/uploads/system/upload s/attachment_data/file/611185/road-lengths-in-greatbritain-2016..pdf.

Department of the Environment Heritage and Local Government (2004) 'Guidelines for road drainage', pp. $1-62$.

Essex Country Council (2018) No Title. Available at: http://www.essexhighways.org/tell-us/road-signs.aspx (Accessed: 14 May 2018).

George, N. and Kershaw, K. (2016) 'Road Use Statistics Great Britain 2016', Department for Transport, (April), p. p.23. doi: 10.1177/014860717900300609.

Heath, H. (1999) 'Information Sheet No. 4', (September), pp. 1-2.

Highway Operational Standards (2018) 'Highway Operational Standards 2018-2028', pp. 1-9.

Highways Agency (2006) 'HD 26/06 Pavement Design', Manual of Contract Documents for Highways works, 7(February 2006).

Highways, W. (2015) Effective demarcation boosts traffic safety. Available at: http://www.worldhighways.com/categories/roadmarkings-barriers-workzoneprotection/features/effective-demarcation-booststraffic-safety/ (Accessed: 7 June 2018). 
Holladay, R. (2014) ExeterFoundry.org. Available at: http://www.exeterfoundry.org.uk/gummed-gullies.php (Accessed: 6 June 2018).

Indicators, M. (2016) 'Caltrans Asset Management Performance Report'.

International Road Federation (2006) 'Maintenance of Road Signs, Markings and Other Safety Assets: A COST EFFECTIVE MEANS OF OPTIMISING ROAD SAFETY'. Available at: http://www.irfnet.ch/filesupload/pdf-files/PTCRS_publication.pdf.

Jamzad, Z. and Assadi, M. (2009) 'Construction of Portland Concrete Pavements Participant's Manual', 15(1), pp. 51-56.

Levik, K. (2001) "How to sell the message "Road maintenance is necessary" to decision makers', First Road Transportation Technology Transfer ..., pp. 460467. Available

http://www.piarc.org/ressources/documents/actesseminaires0102/c3c20-cambodge02/9135,4.2_TC320_2002_Levik.pdf.

Maintenance, H. and Programme, E. (no date) Norfolk's Transport Asset Management Plan 2017/18 - 2021/22. Norfolk, United Kingdom.

Marszalek, Z., Sroka, R. and Zeglen, T. (2015) 'Inductive loop for vehicle axle detection from first concepts to the system based on changes in the sensor impedance components', 2015 20th International Conference on Methods and Models in Automation and Robotics, MMAR 2015, pp. 765-769. doi: 10.1109/MMAR.2015.7283972.

Medd, D. G. P. A. S. R. I. A. I. (2009) Road safety audit. Edited by T. I. O. H. \& TRANSPORTATION.

Officials, A. A. of S. H. and T. (1993) 'Guide for Design of Pavement Structures', Sustainable Waste Management and Recycling: Construction Demolition Waste:Proceedings of the international conference organised by the concrete and masonry research group. Washington D.C.: American Association of State Highway and Transportation Officials, pp. 63-67.

Pavement Systems (2012) Pavement Interactive. Available at: http://www.pavementinteractive.org (Accessed: 10 June 2018).

Research \& Development division of the Highway Department (2013) 'Guidance Notes Catalogue of Road
Defects', (January), pp. 1-53. Available at: https://www.hyd.gov.hk/en/publications_and_publicity/ publications/technical_document/guidance_notes/pdf/G N015B.pdf.

Roads Liaison Group (2010) 'Guidance Document for Highway Infrastructure Asset Valuation’.

Roadware, F. (2010) 'Fugro Roadware Launches ARAN 9000 Surveying System'. Available at: http:/www.roadware.com/media_events/news/2010/arti cle3/.

Royal Borough of Windsor and Maidenhead (2017) 'Royal Borough of Windsor and Maidenhead HIGHWAY SAFETY INSPECTION MANUAL', pp. 1-16.

\section{'STREET LIGHTING MAINTENANCE}

MANAGEMENT PLAN ( Including Telematics )' (2015), 2008(June 2008), pp. 1-38.

The Government of the Hong Kong Special Administrative Region, H. D. (2018) No Title. Available at:

https://www.hyd.gov.hk/en/district and maintenance/r oad/index.html (Accessed: 25 February 2018).

The Local Government \&Municipal Knowledge Base (no date) Road Verge.

Transport Infrastructure Ireland (2017) 'Standardised Public Lighting Inventory Template User Manual', (December). Available at: http://www.tiipublications.ie/library/AM-LHT-0605801.pdf.

UK Highways Agency (2006) 'Requirement for Road. restraint Systems', 2(August 2006).

Workingham (2018) Report a problem with a road or street. Available at: https://selfservice.wokingham.gov.uk/services/report-aproblem-with-a-road-or-

street/?auto=wbc_faulttype $\% 7 \mathrm{C} 859960013 \&$ stepid $=$ df5 6b6bf-3ada-e511-8143-

c4346bad924c\&sessionid=ccc21163-9a69-e811-9cca00155d6b5d65 (Accessed: 7 June 2018).

WSDOT (2017) 'Chapter 3 Pavement Patching and Repair Maintenance of Flexible Pavements Load and Speed Restrictions', in, pp. 1-30. Available at: http:/www.wsdot.wa.gov/publications/manuals/fulltext /M51-01/Chapter3.pdf. 
Table A.1: Road assets and sub classes categories (Queensland Manual) (Anon., 2010)

\begin{tabular}{|l|l|l|}
\hline Level 1 Asset Type & Level 2 Asset Group & $\begin{array}{l}\text { Level 3: Components that Level } \\
\text { 2 implicitly covers in valuation }\end{array}$ \\
\hline Roads & $\begin{array}{l}\bullet \text { Pavement, } \bullet \text { Surfacing, } \bullet \text { Street } \\
\text { Furniture, } \bullet \text { Formation }\end{array}$ & Not Applicable in this manual \\
\cline { 1 - 2 } Structures & $\begin{array}{l}\bullet \text { Bridges, } \bullet \text { Culverts, } \bullet \text { Gantries } \\
\bullet \text { Jetties, Wharves, Pontoons, } \\
\text { Boat Ramps, } \bullet \text { Rock Walls }\end{array}$ \\
\hline ITS \& E & Not Applicable in this level \\
\cline { 1 - 2 } \begin{tabular}{l|l|} 
Corridors, Ancillary Works, \\
Encroachments, Environment
\end{tabular} & Not Applicable in this level \\
\hline $\begin{array}{l}\text { Major Complex Intersection and } \\
\text { Exchanges }\end{array}$ & Not Applicable in this level \\
\hline
\end{tabular}

Table A.2: Road assets categories (California Manual) (Indicators, 2016)

\begin{tabular}{|l|l|l|}
\hline Level 1 Asset Type & Level 2 Asset Group & $\begin{array}{l}\text { Level 3: Components that Level } \\
\text { 2 implicitly covers in valuation }\end{array}$ \\
\cline { 1 - 1 } Pavement & \multirow{2}{*}{ Not Applicable in this manual } & Not Applicable in this manual \\
\hline Bridges & & \\
\hline ITS Elements & & \\
\hline
\end{tabular}

Table A.3: Maintenance techniques of "Concrete" Pavement type and their description.

\begin{tabular}{|l|l|}
\hline Maintenance Technique & Description \\
\hline $\begin{array}{l}\text { PCC (Portland Cement Concrete) full depth } \\
\text { patching }\end{array}$ & $\begin{array}{l}\text { A process that proceeds as follows: extract the flawed } \\
\text { material, insert dowel bars and slab replacements, insert a } \\
\text { material to bond the patch with the slab material and place the } \\
\text { PCC by ensuring that it will not extend the height of the } \\
\text { surrounding slab (Jamzad and Assadi, 2009). }\end{array}$ \\
\hline Partial depth patches & $\begin{array}{l}\text { Similar repair procedure to the full depth patches. Their } \\
\text { difference to the full depth patches is that their area is smaller } \\
\text { and that the patch area should be extended beyond the } \\
\text { damaged area by 75 - 100 mm (3 - 4 inches) (Jamzad and } \\
\text { Assadi, 2009). }\end{array}$ \\
\hline Crack sealing & $\begin{array}{l}\text { Removal of remnants with hot air, followed by sealing } \\
\text { (Officials, 1993) }\end{array}$ \\
\hline $\begin{array}{l}\text { Portland Cement Concrete (PCC) or Hot Mix } \\
\text { Asphalt (HMA) }\end{array}$ & $\begin{array}{l}\text { Remove the pavement layer and apply an overlay (either } \\
\text { Portland Cement Concrete (PCC) or Hot Mix Asphalt (HMA) } \\
\text { (Officials, 1993) }\end{array}$ \\
\hline Insertion of dowel bars & $\begin{array}{l}\text { The bars that are usually used in transverse joints to help the } \\
\text { load transfer) (Concrete Reinforcing Steel Institute, 2000) }\end{array}$ \\
\hline Mechanical roughening or re-surfacing & Using Epoxy (Pavement Systems, 2012) \\
\hline
\end{tabular}

